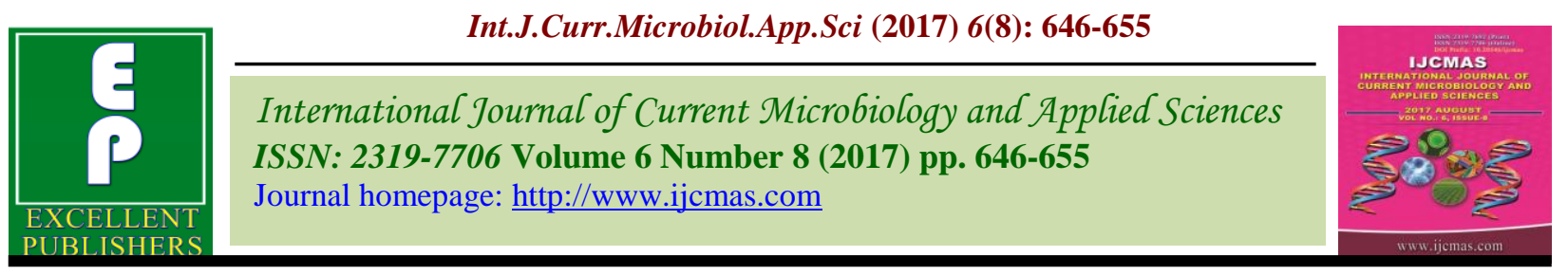

Original Research Article

https://doi.org/10.20546/ijcmas.2017.608.082

\title{
Effect of Potassium and Sulphur Levels on Yield and Yield Attributes of Popcorn (Zea mays Var. Everta)
}

\author{
Pamu Swetha*, Dharmik Solanki, Shalini Kumari and S.G. Savalia \\ Department of Agricultural Chemistry and Soil Science, College of Agriculture, Junagadh \\ Agricultural University, Junagadh - 362 001, Gujarat, India \\ *Corresponding author
}

\section{A B S T R A C T}

Keywords

Rabi popcorn,

Potassium levels,

Sulphur levels, Dry

matter yield, Yield

and yield attributes.

Article Info

Accepted:

04 June 2017

Available Online:

10 August 2017
A field experiment was conducted during 2013-14 rabi season, at the Instructional Farm, College of Agriculture, Junagadh Agricultural University, Junagadh to asses response of popcorn (Zea mays L. everta Sturt) to four levels each of potassium viz., 0, 30, 60 and $90 \mathrm{~kg} \mathrm{~K}_{2} \mathrm{O} \mathrm{ha}^{-1}$ and sulphur viz., 0, 20, 40, $60 \mathrm{~kg} \mathrm{~S} h a^{-1}$ The results of different potassium and sulphur levels depicted that application of potassium @ $60 \mathrm{~kg} \mathrm{~K}_{2} \mathrm{O} \mathrm{ha}^{-1}$

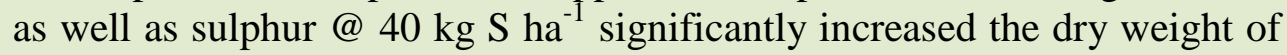
leaves, shoot, root and total plant, at 30,60 DAS and at harvest, cob girth, cob length, number of cobs per plant, number of grains per cob, grain rows per cob, 100 seed weight, seed weight per cob, dry weight of cob, seed yield \& fodder yield.

\section{Introduction}

Maize is one of the most important cereal crop next to rice, wheat and jowar in respect of area and production in India. Maize cultivated over an area of 9.3 million hectares with production of 24.2 million tonnes and average yield of $2602 \mathrm{~kg} / \mathrm{ha}$ in the country (FAO STAT, 2014). Gujarat occupies an area of 5.59 lakh hectares, with production of 7.86 lakh tonnes and productivity of $1953 \mathrm{~kg} / \mathrm{ha}$ (DOA, 2013). According to the character of the kernels, it is classified in various groups among which "popcorn" is major one. Popcorn (Zea mays L. var. everta Sturt) also known as popping corn is popular and nutritious snack food in many parts of World. All parts of corn such as grain, branches and leaves, even corn cob and corn silk is used numerously in human nutrition, fed livestock and poultry and pharmaceutical industry. The kernels of teosinte are readily "popped" for human consumption like modern popcorn. It has tremendous potentially because, it gives more remuneration to the farmer. Potassium and sulphur play a vital role in the nutrition of plants. Fertility analysis of Indian soils has indicated that the soils are deficient in sulphur and medium to low in the potash. In fact, these nutrients are lacking mostly in the soils of Saurashtra region. Therefore, application of chemical fertilizers becomes essential to raise the crop yield. Potassium is an essential 
element for plant growth and development and is the most abundant cation in plants, making up 3-5\% of a plant's total dry weight. Sulphur plays an important role in enhancing the productivity of pop corn crop.

\section{Materials and Methods}

The experiment was conducted during rabi season 2013-14 in D-5 plot of Instructional Farm at Krushigadh, College of Agriculture, Junagadh Agricultural University, Junagadh. It is Geographically Junagadh is situated at $21.5^{\circ} \mathrm{N}$ latitude and $70.5^{\circ} \mathrm{E}$ longitude with an altitude of $60 \mathrm{~m}$ above the mean sea level. The experiments were laid out in Factorial Randomized Block Design having 16 treatments with three replications. The gross and net plot sizes were $5.0 \mathrm{~m} \mathrm{X} 3.6 \mathrm{~m}$ and 4.2 $\mathrm{m} \times 2.4 \mathrm{~m}$, respectively. The experiment consisted of 4 levels of potassium $(0,30,60$ and $\left.90 \mathrm{~kg} \mathrm{~K}_{2} \mathrm{O} \mathrm{ha}{ }^{-1}\right)$ and 4 levels of sulphur $(0$, 20, 40, $60 \mathrm{~kg} \mathrm{~S} \mathrm{ha}^{-1}$ ).

The soil of the experimental field was medium black calcareous soil with $\mathrm{pH} 7.9$ and EC $0.35 \mathrm{dS} \mathrm{m} \mathrm{m}^{-1}$. The crop was fertilized with potassium and sulphur as per treatment allotted to each plot in the form of MOP and Cosavet fertis. WG. (90\%) in basal application and nitrogen and phosphorus in the form of urea, dammonium phosphate in the furrows, respectively $1 / 3^{\text {rd }}$ nitrogen applied before sowing, $1 / 3^{\text {rd }}$ at 20 days after sowing and remaining $1 / 3^{\text {rd }}$ at 40 days after sowing, and phosphorus applied as basal. Amber popcorn variety was used as planting material in this study. The seeds were dibbled at a spacing of $60 \mathrm{~cm} \times 20 \mathrm{~cm}$ using a seed rate of $15 \mathrm{~kg} \mathrm{ha}^{-1}$ during the last week of November.

Five plants were selected at random from each plot to record dry matter production per plant and yield parameters, seed yield and fodder yield $\left(\mathrm{kg} \mathrm{ha}{ }^{-1}\right)$ by using standard procedure. Similarly for grain yield, cobs of each plot after removing were shelled with the help of machine sheller and were weighed to have grain yield per plot. All other recommended agronomic practices and plant protection measures were carried out to all treatments uniformly during the course of study.

\section{Results and Discussion}

\section{Effect of Potassium}

\section{Dry matter yield}

The dry weight of leaves, shoot, root and total plant were significantly recorded higher with $60 \mathrm{~kg} \mathrm{~K}_{2} \mathrm{O} \mathrm{ha}^{-1}\left(\mathrm{~K}_{3}\right)$ at 30, 60 DAS and leaves, shoot, root, seed and total plant at harvest (Table 1). The leaves were remain at par with $90 \mathrm{~kg} \mathrm{~K}_{2} \mathrm{O} \mathrm{ha}^{-1}\left(\mathrm{~K}_{4}\right)$ at $30,60 \mathrm{DAS}$ and $30 \mathrm{~kg} \mathrm{~K}_{2} \mathrm{O} \mathrm{ha}^{-1}\left(\mathrm{~K}_{2}\right)$ and $90 \mathrm{~kg} \mathrm{~K}_{2} \mathrm{O} \mathrm{ha}^{-1}$ $\left(\mathrm{K}_{4}\right)$ at harvest. Shoot was remain at par with $30 \mathrm{~kg} \mathrm{~K}_{2} \mathrm{O} \mathrm{ha}{ }^{-1}\left(\mathrm{~K}_{2}\right)$ and $90 \mathrm{~kg} \mathrm{~K}_{2} \mathrm{O} \mathrm{ha}{ }^{-1}\left(\mathrm{~K}_{4}\right)$ at $30 \mathrm{DAS}$ and at harvest, the root was remain at par with $90 \mathrm{~kg} \mathrm{~K}_{2} \mathrm{O} \mathrm{ha}^{-1}\left(\mathrm{~K}_{4}\right)$ at harvest, seed was at par with $30 \mathrm{~kg} \mathrm{~K}_{2} \mathrm{O} \mathrm{ha}^{-1}\left(\mathrm{~K}_{2}\right)$ and $90 \mathrm{~kg} \mathrm{~K}_{2} \mathrm{O} \mathrm{ha}^{-1}\left(\mathrm{~K}_{4}\right)$ at harvest, while total plant was at par with $90 \mathrm{~kg} \mathrm{~K}_{2} \mathrm{O} \mathrm{ha}{ }^{-1}\left(\mathrm{~K}_{4}\right)$ at 30 DAS and harvest.

The application of potassium was found to increase the shoot dry weight of maize which may be due to selective and adequate potassium uptake in plant tissue (Kaya et al., 2009). The adverse effect of ammonium on root growth in Arabidopsis in absence of potassium (Cao et al., 1993) and this harmful effect can be alleviated by potassium supply which activates the enzymes involved in ammonium assimilation (Hagin et al., 1990) through which root dry weight increased in maize crop. Tacket and Pearson (1964) reported that potassium doubles the weight of roots at harvest. 
It can be attributed to high capability of photosynthesis by increasing the capturing carbon and enzyme rubisco and encouraging synthesis and matter transport in developing plant which helps to increase the dry weight of leaves, shoot, root and total dry weight with potassium levels. These results are already in agreement with those reported by Kalpana and Krishnarajan (2002) and Maurya et al., (2004)) for total dry matter, Bhatt and Jain (2012), Aslam et al., (2013) for shoot dry weight.

\section{Yield attributes}

An examination of data (Table 2) showed that different levels of potassium exhibited their significant influence on yield attributes. Application of $60 \mathrm{~kg} \mathrm{~K}_{2} \mathrm{O} \mathrm{ha}^{-1}\left(\mathrm{~K}_{3}\right)$ recorded significantly the higher cob girth $(15.67 \mathrm{~cm})$, cob length $(18.61 \mathrm{~cm})$, number of cobs per plant (1.47), number of grains per cob (250.41), grain rows per cob (14.83), 100 seed weight $(23.11 \mathrm{~g})$, seed weight per cob (57.97 g), dry weight of cob (32.0 g), whereas the lowest was observed with $\mathrm{K}_{1}$ (control).

Potassium is essential for many physiological processes such as photosynthesis and formation of ferredoxin which functions as electron transporter in photosynthesis (Zehler et al., 1981), translocation of photosynthates into sink, activation of enzymes and it increases the NUE increase the metabolites and nutrients to develop reproductive structures (Brar et al.,2012) seems to have resulted in increased cob girth, cob length, number of cobs, number of grains per cob, grain rows per cob, 100 grain weight and seed weight. The findings are close agreement with those obtained by Tariq et al., (2011) and Chaudari (2012).

\section{Yield}

A perusal of data (Table 2) revealed that different levels of potassium exerted their significant influence on seed yield and fodder yield. Among various levels the $K_{3}(60 \mathrm{~kg}$ $\mathrm{K}_{2} \mathrm{O}$ ha $^{-1}$ ) gave significantly higher seed yield and fodder yield with the value of $3677 \mathrm{~kg} \mathrm{ha}^{-1}$ and $6447 \mathrm{~kg} \mathrm{ha}^{-1}$, respectively, which were remained at par with $\mathrm{K}_{4}\left(90 \mathrm{~kg} \mathrm{~K}_{2} \mathrm{O} \mathrm{ha}{ }^{-1}\right)$ with the value of $3558 \mathrm{~kg} \mathrm{ha}^{-1}$ and $5804 \mathrm{~kg} \mathrm{ha}^{-1}$, respectively.

The lowest seed yield (2979 $\mathrm{kg} \mathrm{ha}^{-1}$ ) and fodder yield (5025 kg ha ${ }^{-1}$ ) was recorded under $\mathrm{K}_{1}$ (control). Potassium due to its impact on many physiological processes plays an important role in water use by crop plants (Grzebisz et al., 2013 and Oosterhuis et al., 2013). A main function of $\mathrm{K}$ is unloading sugars from chloroplasts to phloem cells, and from phloem cells into storage cells such as grains, (Salisbury and Ross, 1978). Therefore, the availability of $\mathrm{K}$ during initial stage to until the end of grain filling increases the filled grain number in cob and grain weight, as observed in these studies. In addition, the presence of $\mathrm{K}$ is known to improve the $\mathrm{N}$ use efficiency in rice and maize, (Kanwar et al., 1973 and Rao, 1985); it aids to uptake the other nutrients, (Wakeel et al., 2002). K nutrition collectively added a higher yield potential to the popcorn crop. The results are also in conformity with Senaratne et al., 2006.

\section{Effect of sulphur}

\section{Dry matter yield}

The dry weight of leaves, shoot, root and total plant were significantly recorded higher with $\mathrm{S}_{3}\left(40 \mathrm{~kg} \mathrm{~S} \mathrm{ha}^{-1}\right)$ at 30,60 DAS and leaves, shoot, root, seed and total plant at harvest (Table 1; Figs. 1 and 2). The leaves were remain at par with $S_{4}\left(60 \mathrm{~kg} \mathrm{~S} \mathrm{ha}^{-1}\right)$ at 30,60 DAS and at harvest, shoot was remain at par with $\mathrm{S}_{4}\left(60 \mathrm{~kg} \mathrm{~S} \mathrm{ha}^{-1}\right)$ at 30DAS and at harvest, root and seed was at par with $\mathrm{S}_{4}(60$ $\left.\mathrm{kg} \mathrm{S} \mathrm{ha}^{-1}\right)$ at harvest, while total plant at par with $\mathrm{S}_{4}\left(60 \mathrm{~kg} \mathrm{~S} \mathrm{ha}^{-1}\right)$ at 30 DAS. 
Table.1 Effect of potassium and sulphur on dry matter yield of popcorn at 30 DAS, 60DAS and at Harvest

\begin{tabular}{|c|c|c|c|c|c|c|c|c|c|c|c|c|c|}
\hline \multicolumn{14}{|c|}{ Dry matter yield } \\
\hline \multirow[t]{2}{*}{ Treatments } & \multicolumn{4}{|c|}{ 30DAS } & \multicolumn{4}{|c|}{ 60DAS } & \multicolumn{5}{|c|}{ Harvest } \\
\hline & Leaves & Shoot & Root & $\begin{array}{l}\text { Total } \\
\text { plant }\end{array}$ & Leaves & Shoot & Root & $\begin{array}{l}\text { Total } \\
\text { plant }\end{array}$ & Leaves & Shoot & Root & seed & $\begin{array}{l}\text { Total } \\
\text { plant }\end{array}$ \\
\hline \multicolumn{14}{|c|}{ Potassium levels $\left(\mathrm{kg} \mathrm{K}_{2} \mathrm{O} \mathrm{ha}^{-1}\right)$} \\
\hline $\mathrm{K}_{1}-0$ & 4.14 & 22.67 & 2.21 & 29.03 & 18.67 & 28.52 & 9.39 & 56.57 & 27.83 & 40.94 & 14.65 & 55.78 & 139.54 \\
\hline $\mathrm{K}_{2}-30$ & 4.23 & 24.25 & 2.32 & 30.80 & 20.17 & 31.87 & 9.56 & 61.60 & 29.08 & 44.58 & 15.18 & 58.69 & 147.54 \\
\hline $\mathrm{K}_{3}-60$ & 4.47 & 25.25 & 2.79 & 32.51 & 21.33 & 36.21 & 10.58 & 68.12 & 30.25 & 45.96 & 16.21 & 61.43 & 153.85 \\
\hline $\mathrm{K}_{4}-90$ & 4.34 & 24.67 & 2.41 & 31.42 & 20.67 & 33.51 & 9.77 & 63.95 & 29.83 & 44.71 & 15.42 & 59.75 & 149.70 \\
\hline S.Em. \pm & 0.07 & 0.44 & 0.06 & 0.45 & 0.36 & 0.72 & 0.18 & 0.71 & 0.42 & 0.78 & 0.30 & 1.05 & 1.50 \\
\hline C.D. $(\bar{P}=0.05)$ & 0.19 & 1.28 & 0.18 & 1.31 & 1.03 & 2.07 & 0.51 & 2.05 & 1.21 & 2.26 & 0.87 & 3.02 & 4.33 \\
\hline \multicolumn{14}{|c|}{ Sulphur levels $\left(\mathrm{kg} \mathrm{S} \mathrm{ha}^{-1}\right)$} \\
\hline$S_{1-0}$ & 4.19 & 23.33 & 2.26 & 29.79 & 19.33 & 28.66 & 9.46 & 57.45 & 28.58 & 41.19 & 14.57 & 56.38 & 140.72 \\
\hline $\mathrm{S}_{2}-20$ & 4.20 & 23.83 & 2.29 & 30.33 & 19.83 & 31.89 & 9.50 & 61.22 & 28.67 & 43.58 & 15.19 & 57.38 & 144.82 \\
\hline $\mathrm{S}_{3}-40$ & 4.41 & 25.17 & 2.69 & 32.27 & 21.17 & 35.87 & 10.51 & 67.54 & 30.33 & 46.83 & 16.13 & 61.80 & 155.08 \\
\hline $\mathrm{S}_{4}-60$ & 4.38 & 24.50 & 2.48 & 31.37 & 20.50 & 33.70 & 9.82 & 64.02 & 29.42 & 44.59 & 15.58 & 60.09 & 149.68 \\
\hline S.Em. \pm & 0.07 & 0.44 & 0.06 & 0.45 & 0.36 & 0.72 & 0.18 & 0.71 & 0.42 & 0.78 & 0.30 & 1.05 & 1.50 \\
\hline C.D. $(\mathrm{P}=0.05)$ & 0.19 & 1.28 & 0.18 & 1.31 & 1.03 & 2.07 & 0.51 & 2.05 & 1.21 & 2.26 & 0.87 & 3.02 & 4.33 \\
\hline \multicolumn{14}{|c|}{ KxS Interaction } \\
\hline S.Em. \pm & 0.13 & 0.89 & 0.12 & 0.91 & 0.71 & 1.43 & 0.35 & 1.42 & 0.84 & 1.56 & 0.61 & 2.09 & 3 \\
\hline C.D. $(\mathrm{P}=0.05)$ & $\mathrm{NS}$ & NS & NS & NS & NS & NS & NS & NS & $\mathrm{NS}$ & NS & NS & NS & NS \\
\hline C.V.\% & 5.33 & 6.53 & 8.67 & 5.07 & 6.11 & 7.63 & 6.24 & 3.92 & 4.96 & 6.14 & 6.83 & 6.16 & 3.51 \\
\hline
\end{tabular}

Table.2 Effect of potassium and sulphur on yield and yield attributes of popcorn

\begin{tabular}{|c|c|c|c|c|c|c|c|c|c|c|}
\hline Treatments & $\begin{array}{l}\text { Cob girth } \\
\text { (cm) }\end{array}$ & $\begin{array}{l}\text { Cob length } \\
\text { (cm) }\end{array}$ & $\begin{array}{c}\text { Number of } \\
\text { cobs per plant }\end{array}$ & $\begin{array}{c}\text { Number of } \\
\text { grains per cob }\end{array}$ & $\begin{array}{c}\text { Grain rows } \\
\text { per cob }\end{array}$ & $\begin{array}{c}100 \text { seed } \\
\text { weight }(\mathrm{g})\end{array}$ & $\begin{array}{l}\text { Seed weight } \\
\text { per cob }(g)\end{array}$ & $\begin{array}{l}\text { Dry weight of } \\
\text { cob }(\mathrm{g})\end{array}$ & $\begin{array}{c}\text { Seed yield } \\
(\mathrm{kg} / \mathrm{ha})\end{array}$ & $\begin{array}{c}\text { Fodder yield } \\
(\mathrm{kg} / \mathrm{ha})\end{array}$ \\
\hline \multicolumn{11}{|c|}{ Potassium levels $\left(\mathrm{kg} \mathrm{K}_{2} \mathrm{O}\right.$ ha $\left.^{-1}\right)$} \\
\hline $\mathrm{K}_{1}-0$ & 12.33 & 14.58 & 1.16 & 236.18 & 12.58 & 18.10 & 42.76 & 18.73 & 2979 & 5025 \\
\hline $\mathrm{K}_{2}-30$ & 14.08 & 16.45 & 1.32 & 242.97 & 14.00 & 20.70 & 50.35 & 25.08 & 3393 & 5323 \\
\hline $\mathrm{K}_{3}-60$ & 15.67 & 18.61 & 1.47 & 250.41 & 14.83 & 23.11 & 57.97 & 32.00 & 3677 & 6447 \\
\hline $\mathrm{K}_{4}-90$ & 15.00 & 17.21 & 1.38 & 245.32 & 14.50 & 21.69 & 53.25 & 28.08 & 3558 & 5804 \\
\hline S.Em. \pm & 0.43 & 0.48 & 0.04 & 2.91 & 0.44 & 0.42 & 1.28 & 0.84 & 84.1 & 233.1 \\
\hline C.D. $(\mathrm{P}=0.05)$ & 1.23 & 1.40 & 0.12 & 8.41 & 1.26 & 1.22 & 3.71 & 2.41 & 242.8 & 673.3 \\
\hline \multicolumn{11}{|c|}{ Sulphur level $\left(\mathrm{kg} \mathrm{S} \mathrm{ha}^{-1}\right)$} \\
\hline $\mathrm{S}_{1}-0$ & 12.92 & 15.88 & 1.17 & 237.37 & 12.58 & 19.89 & 47.38 & 20.90 & 3182 & 4907 \\
\hline $\mathrm{S}_{2}-20$ & 13.83 & 16.08 & 1.32 & 242.86 & 13.83 & 20.49 & 49.86 & 24.92 & 3308 & 5671 \\
\hline $\mathrm{S}_{3}-40$ & 15.58 & 17.58 & 1.43 & 249.63 & 14.83 & 22.08 & 55.23 & 30.75 & 3628 & 6192 \\
\hline $\mathrm{S}_{4}-60$ & 14.75 & 17.32 & 1.40 & 245.02 & 14.67 & 21.14 & 51.86 & 27.33 & 3489 & 5828 \\
\hline S.Em. + & 0.43 & 0.48 & 0.04 & 2.91 & 0.44 & 0.42 & 1.28 & 0.84 & 84.1 & 233.1 \\
\hline C.D. $(\mathbf{P}=0.05)$ & 1.23 & 1.40 & 0.12 & 8.41 & 1.26 & 1.22 & 3.71 & 2.41 & 242.8 & 673.3 \\
\hline \multicolumn{11}{|l|}{ KxS Interaction } \\
\hline S.Em. \pm & 0.86 & 0.97 & 0.09 & 5.83 & 0.87 & 0.85 & 2.57 & 1.67 & 168.1 & 466.3 \\
\hline C.D. $(\bar{P}=0.05)$ & NS & NS & NS & NS & NS & NS & NS & NS & NS & NS \\
\hline C.V.\% & 10.38 & 10.02 & 11.22 & 4.14 & 10.82 & 7.00 & 8.71 & 11.14 & 8.56 & 14.29 \\
\hline
\end{tabular}


Fig.1 Dry weight of leaves, shoot, root and seed $\left(\mathrm{g} \mathrm{plant}^{-1}\right)$ within plant at different growth stages under different potassium levels

$30 \mathrm{~kg} \mathrm{~K}_{2} \mathrm{O} \mathrm{ha}{ }^{-1}$
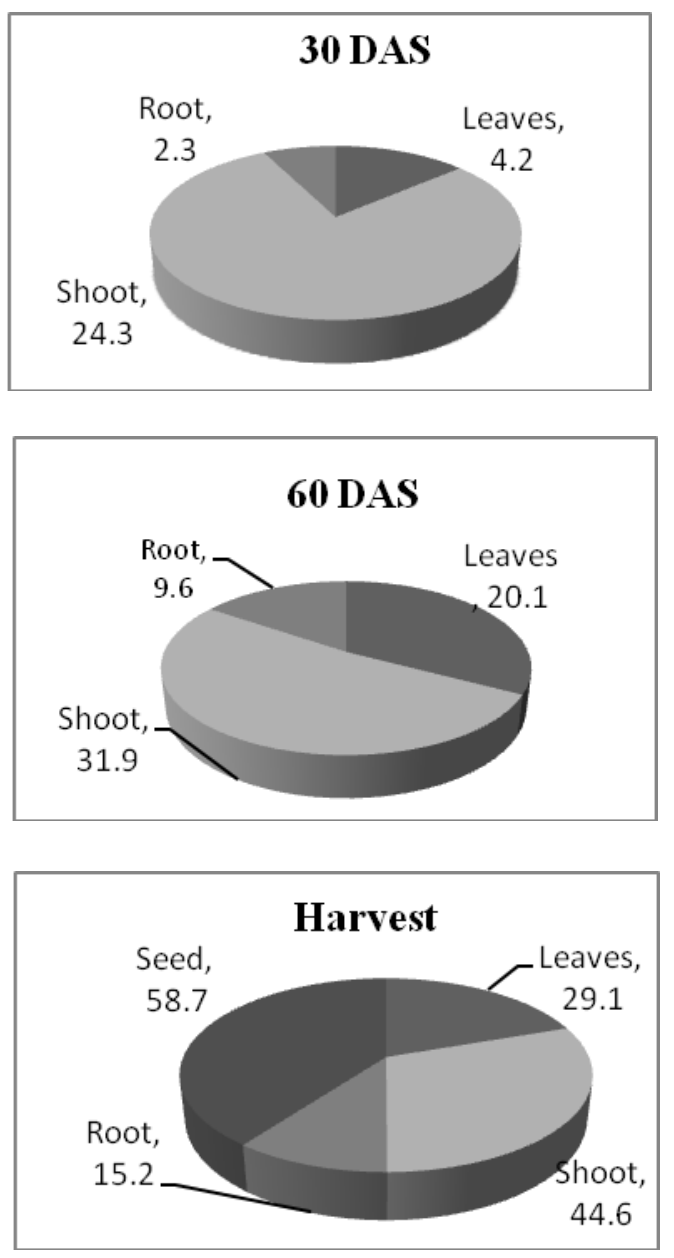

$60 \mathrm{~kg} \mathrm{~K}_{2} \mathrm{Oha}^{-1}$
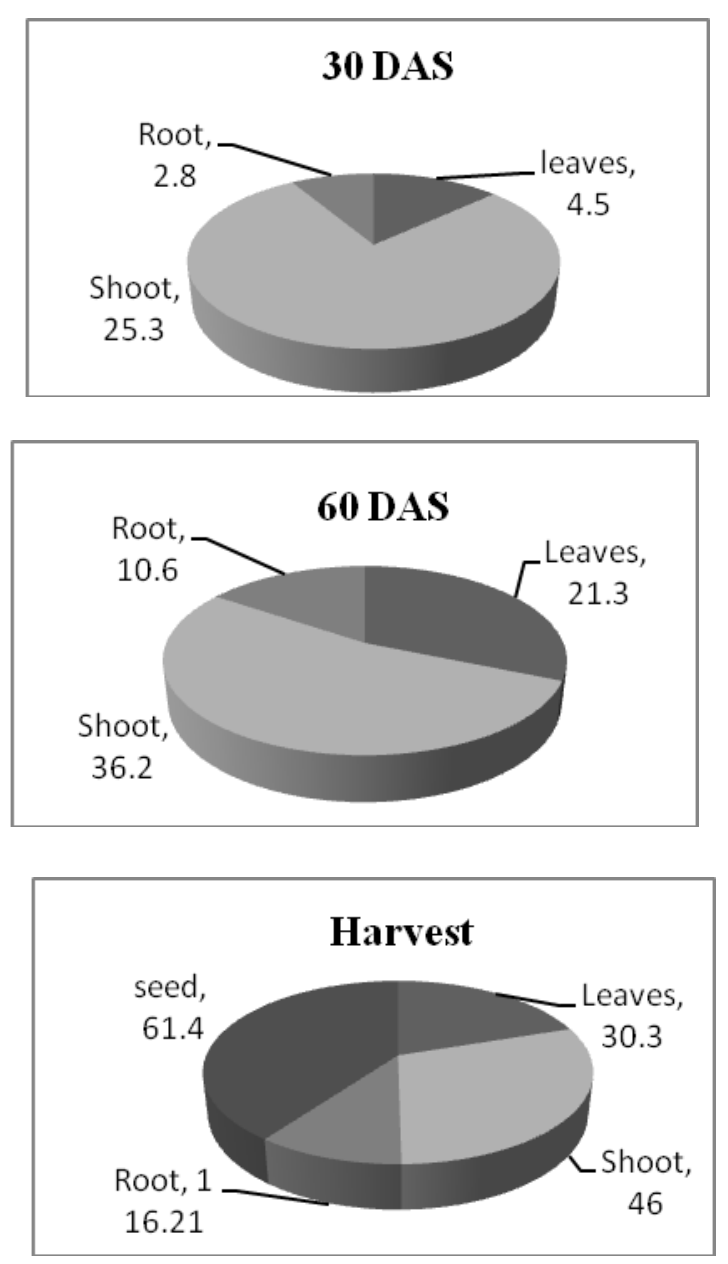

$90 \mathrm{~kg} \mathrm{~K}_{2} \mathrm{O} \mathrm{ha}^{-1}$
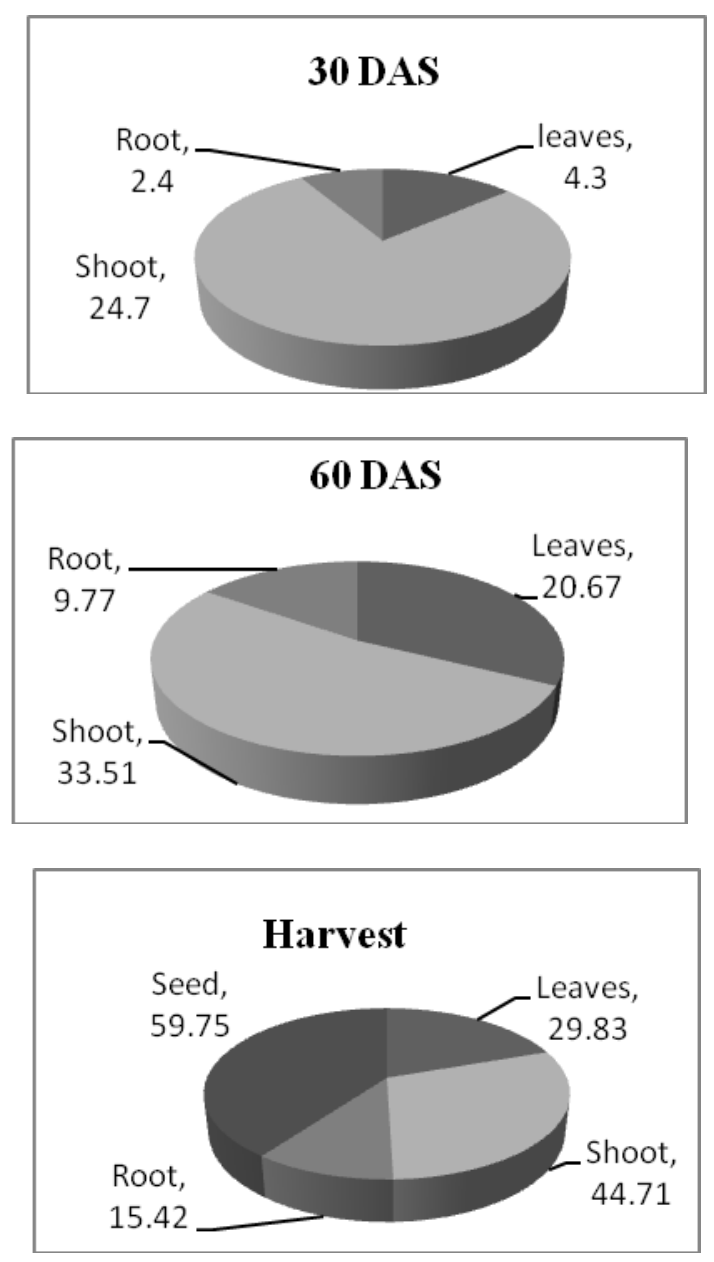
Fig.2 Dry weight of leaves, shoot, root and seed $\left(\mathrm{g} \mathrm{plant}^{-1}\right)$ within plant at different growth stages under different sulphur levels

$20 \mathrm{~kg} \mathrm{Sha}^{-1}$
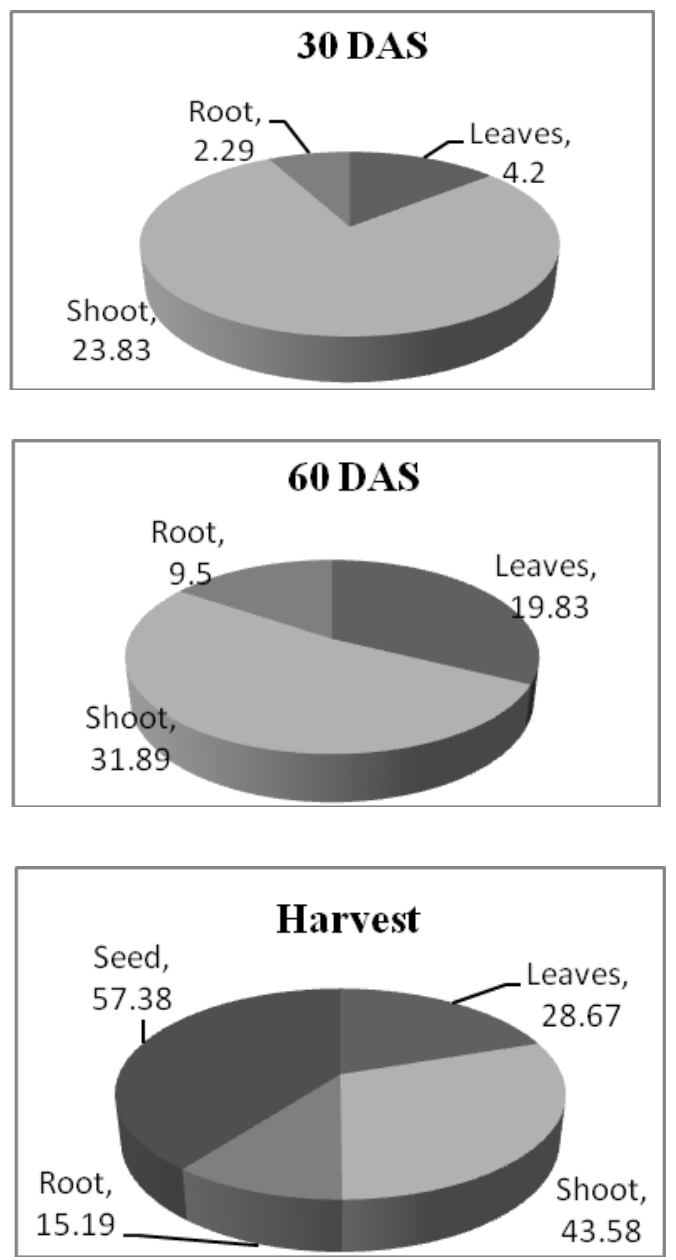

$40 \mathrm{~kg} \mathrm{Sha}{ }^{-1}$
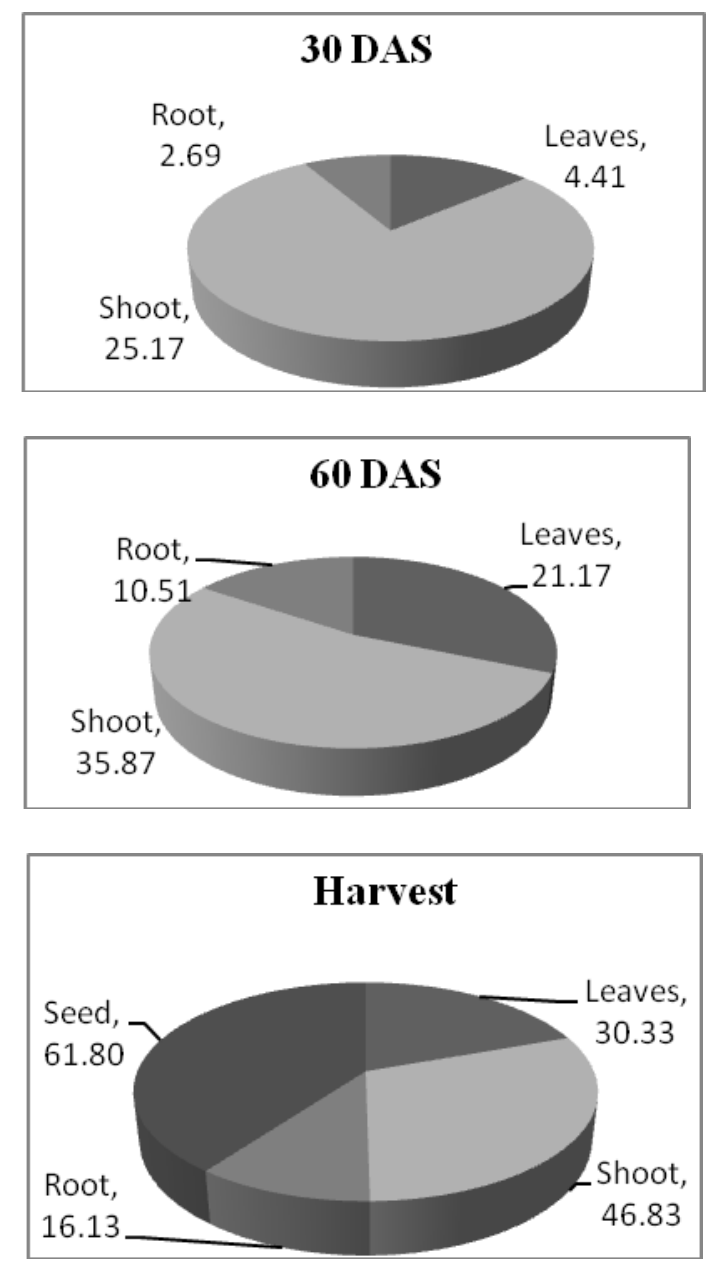

$60 \mathrm{~kg} \mathrm{Sha}{ }^{-1}$
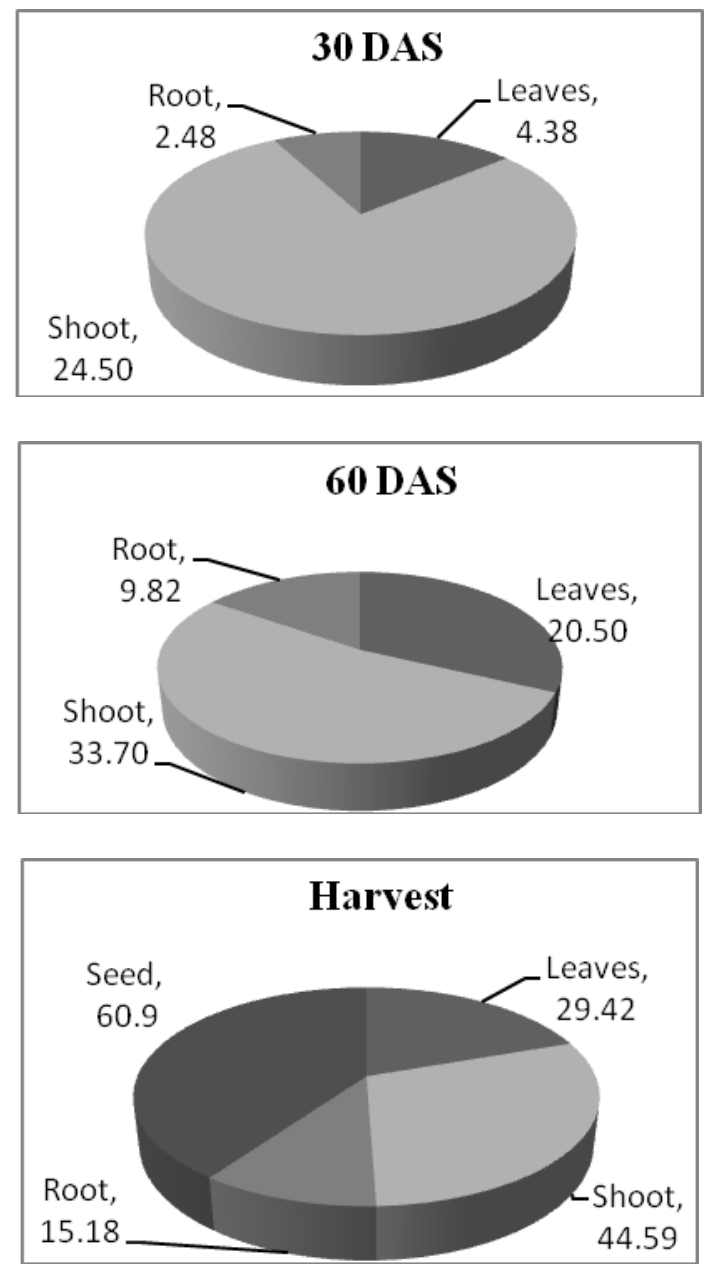

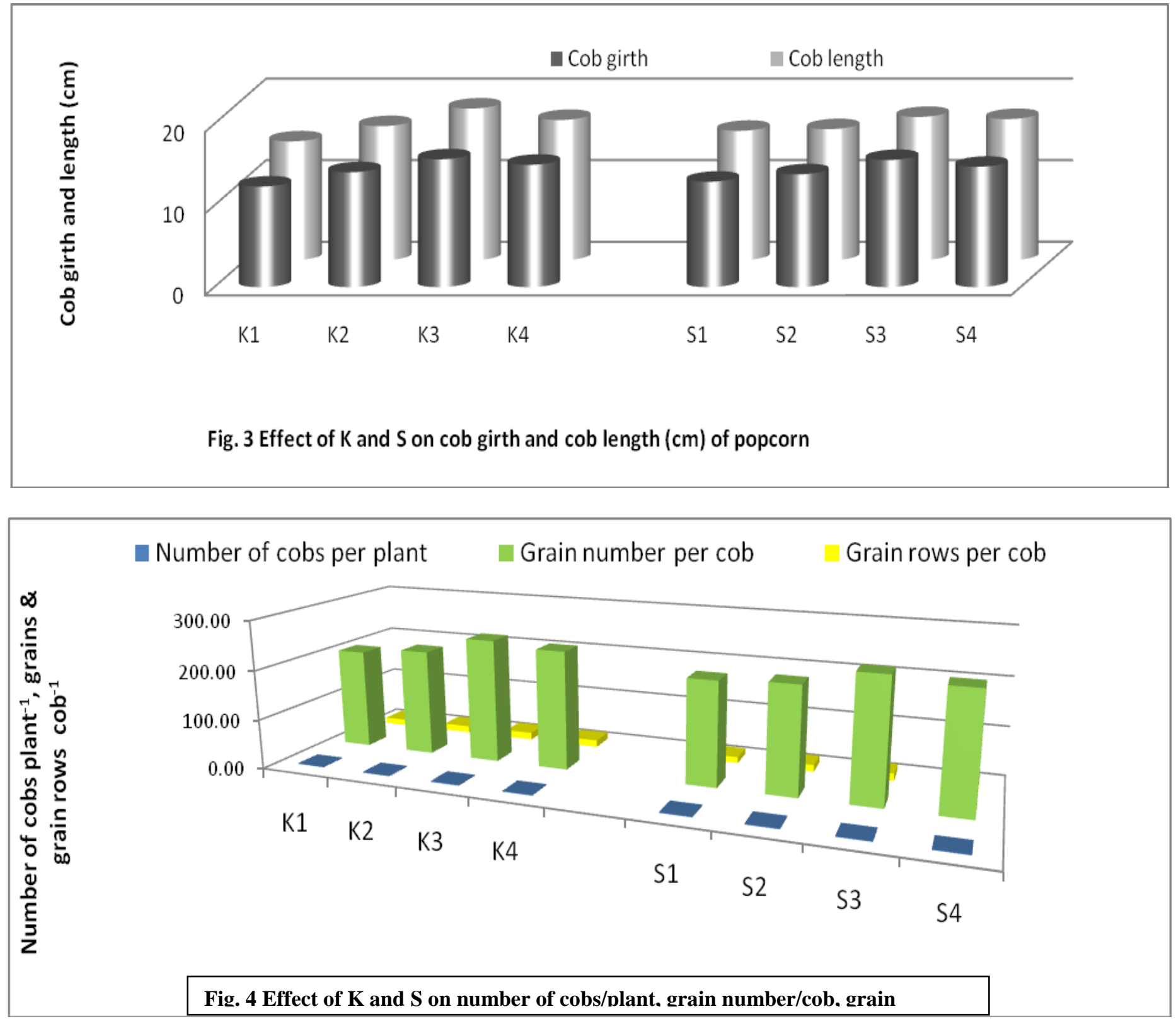
The application of $40 \mathrm{~kg} \mathrm{~S} \mathrm{ha}^{-1}$ significantly increased the uptake of nutrients by plant parts, improved the yield attributes, growth parameters, ultimately resulted in higher dry matter per plant (leaf, stem, root and seed). The similar findings were also recorded by Dechassa et al., (2013) and Nanthakumar et al., (2014) (Fig. 3).

\section{Yield attributes}

An appraisal of data (Table 2) showed that various levels of sulphur exerted their significant effect on yield attributes. Application of $40 \mathrm{~kg} \mathrm{~S}$ ha $^{-1}\left(\mathrm{~S}_{3}\right)$ recorded significantly the maximum cob girth $(15.58 \mathrm{~cm})$, cob length $(17.58 \mathrm{~cm})$, number of cobs per plant (1.43), number of grains per cob (249.63), grain rows per cob (14.83), 100 seed weight $(22.08 \mathrm{~g})$, seed weight per cob $(55.23 \mathrm{~g})$, dry weight of cob, whereas the lowest was observed with $\mathrm{S}_{1}$ (control). $\mathrm{S}$ improved the nutritional environment and favorably influenced the carbohydrate metabolism due to role of $\mathrm{S}$ in energy transformation and activation of enzymes. Rise in different yield attributing characters were also recorded by Dechassa et al., (2013) and Nanthakumar et al., (2014). More number of bigger sized cobs per plant might have accommodated more number of grains providing sufficient space for development of an individual grain, leading to higher 100grain weight, seed weight per cob and dry weight of cob (Mahmood et al., 1994 and Grobler et al., 1999) (Fig. 4).

\section{Yield}

The data presented in table 2 indicated that various levels of sulphur manifested their significant influence on seed yield and fodder yield. Application of $40 \mathrm{~kg} \mathrm{~S} \quad \mathrm{ha}^{-1}\left(\mathrm{~S}_{3}\right)$ recorded significantly the higher seed yield $\left(3628 \mathrm{~kg} \mathrm{ha}^{-1}\right)$ and fodder yield $\left(6192 \mathrm{~kg} \mathrm{ha}^{-}\right.$ $\left.{ }^{1}\right)$, seed yield was remained at par with $\mathrm{S}_{4}$
(3489 $\mathrm{kg} \mathrm{ha}^{-1}$ ) and fodder yield was remained at par with $\mathrm{S}_{4}\left(5828 \mathrm{~kg} \mathrm{ha}^{-1}\right)$ and $\mathrm{S}_{2}(5671 \mathrm{~kg}$ $\left.\mathrm{ha}^{-1}\right)$. The lowest seed yield and fodder yield were observed under $S_{1}$ (control). As these growth and yield attributes as well as nutrients uptake showed significant increase in grain and fodder yields with sulphur fertilization. The similar observations were also recorded by Bhatt and Jain (2012), Sutar (2012), Ahmad et al., (2013) and Nanthakumar et al., (2014).

Based on the experimental results, it can be concluded that significantly the higher seed and fodder yield, yield attributes were obtained from rabi popcorn (cv. Amber) by fertilizing the crop with potassium $60 \mathrm{~kg} \mathrm{~K}_{2} \mathrm{O}$ $\mathrm{ha}^{-1}\left(\mathrm{~K}_{3}\right)$ and sulphur up to $40 \mathrm{~kg} \mathrm{~S} \mathrm{ha}^{-1}\left(\mathrm{~S}_{3}\right)$ in medium black calcareous soils of South Saurashtra region of Gujarat.

\section{References}

Ahmad, K. M., Mohammad A. and Matin J. M. 2013. The effect of sulphur application on yield and yield components of corn in two different planting methods in saline conditions. International J. of Agro, 4 (7): 14741478.

Aslam, M., Shahid, M., Zamir, I., Afzal, I., and Yaseen, M. 2013. Morphological and physiological response of maize hybrids to potassium application under drought stress. J. Agril. Res., 51(4).

Bhatt, R.K.B. and Jain, N.K. 2012. Response of sweet corn (Zea mays (L.) Saccharata sturt) to sulphur and zinc fertilization. Res. on Crops, 13(2):760763.

Brar, M.S., Preeti, S., Amandeep Singh and Saandhu, S.S. 2012. Nitrogen Use Efficiency (NUE), Growth, Yield Parameters and Yield of Maize (Zea mays L.) as Affected by $\mathrm{K}$ application Res., 30 (March). 
Cao, Y.A.D.M., Glass and Nigel, M.C. 1993. Ammonium inhibition of Arabidopsis root growth can be reversed by Potassium and by auxin resistance mutations. Plant Physiology, 102:983989.

Chaudhari, 2012. Effect of potassium and sulphur on growth, yield and quality of summer pearl millet. M.sc. thesis Dept. of Agro.

DOA, 2013. District wise area, production and yield per hectare of important food and non-food in Gujarat state. Directorate of Agril. Gandinagar, Gujarat.

Dechassa, C.S. Hunshal, S.M. Hiremath, J.S. Awaknavar, M.C. Wali, B.T. Nadagouda and Chandrashekar, C.P. 2013. Performance of maize (Zea mays L.) hybrids as influenced by different levels of nitrogen, phosphorus, potassium and sulphur application. Karnataka J. Agril. Sciences. 26 (2): 194-199.

FAO STAT, 2014. Crop production datamaize 2014. FAO org.

Grobler, L., Bloem, A.A. and Claassens, A.S. 1999. A critical soil sulphur level for maize (Zea mays L.) grown in a glass house. Dept. of Plant and Soil Sciences, 16 (4): 204-206.

Grzebisz, W., Gransee, A., Szczepaniak, W. and Diatta, J.B. 2013. The effects of potassium fertilization on water useefficiency in crop plants. J. Plant Nutrition Soil Science, 176: 355-374.

Hagin, J., Olson. S.R. and Shaviv. 1990. Review of interaction of ammoniumnitrate and potassium nutrition of crops. J. Plant Nutrition, 13:1211-1226.

Haji,M. A.A., Bukhsh, A., Ahmad, R., Ishaque, M and Malik, A. U. 2009. Response of maize hybrids to varying potassium application in Pakistan. Pak. J. Agri. Sci., 46(3):179-184.

Kalpana, R. and Krishnarajan, J. 2002. Effect of dose and time of application on yield and quality of baby corn. Agril. Sci. Digest, 22(1): 59-60.

Kanwar, J.S., Das, M.N., Sardana, M.G. and Bapat S.R. 1973. Economics of fertilizer use in rice in farmers' fields. Fertilizer News, 18(1): 71-88.

Kaya, M., Kucukyumuk, Z. and Erdal, I. 2009. Effects of elemental sulphur and sulphur containing waste on nutrient concentrations and growth of bean and corn plants grown on a calcareous soil. African J. Biotech, 8 (18): 4481-4489.

Mahmood, T. 1994. Impact of water and nutrient management on growth, yield and quality of maize (Zea mays L.), Ph.D. Thesis, Dept. of Agro., Univ. of Agril, Faisalabad.

Maurya, K.L. Sharma, H.P. Tripathi, H.P. and Sher Singh, 2004. Effect of fertility levels of nitrogen and sulphur on growth yield and quality of winter maize. Haryana J. Agro, 20(1/2): 80-81.

Nanthakumar, S., Panneerselvam, P. and Krishnakumar, S., 2014. Effect of phosphorus and sulphur on growth, yield and quality parameters of hybrid maize. Int. J. Adv. Life Sci. (IJALS), 7(1):85-92.

Oosterhuis, D.M., Loka, D.A. and Raper, T.B. 2013. Potassium and stress alleviation: Physiological functions and management of cotton. J. Plant Nutrition Soil Sci., 176: 331-343.

Rao, M.V. 1985. Use of fertilizers. Chapter 17: In: Rice Research in India. Eds. P.L. Jaiswal, A.M. Wadhwani, R. Singh, N.N. Chhabra and N. Chhabra. Allied Publ. Pvt. Ltd. New Delhi, India, pp: 416-34.

Salisbury, F.B. and Ross, C.W. 1978. Mineral nutrition. Chapter 6: In Plant Physiology, Third Edition, Wadswarth Inc. Belmont, California. pp 79-109.

Senaratne L. Ranamukhaarachchi and Willoram M.R. (2006). The effect of 
straw, stubble and potassium on grain yield of rice in rice-rice cropping systems in the mid-country wet zone of srilanka. Science Asia, 32:151-158.

Sutar, R. K. 2012. Response of maize to different sources and levels of sulphur. Unv. of Agril. Sci, Karnataka State, India. Th10416.

Tackett, J.K. and Pearson, R.W. 1964. Oxygen requirement of cotton seedling root for penetration of compacted soil cores. Soil sciences. Amer. Procedure, 28:600-605.

Tariq, M., Saeed, A., Nisar, M., Main, I.A. and Afzal, M. 2011. Effect of potassium rates and sources on the growth performance and chloride accumulation of maize in two different textured soils of Haripur, Hazara Division. Sarhad J. Agriculture, 3:415-422.

Wakeel, A., Aziz, T. and Iqbal, M. 2002. Effect of different potassium levels and soil texture on growth and nutrient uptake of maize. Pakistan J. Agril Sciences, 39(2): 99-103.

Zehler, E. and Kreipe, H. 1981. Potassium sulphate and potassium chloride, their influence on yield and quality of cultivated crops. IPR research topics, No. 9.

\section{How to cite this article:}

Pamu Swetha, Dharmik Solanki, Shalini Kumari and Savalia, S.G. 2017. Effect of Potassium and Sulphur Levels on Yield and Yield Attributes of Popcorn (Zea mays Var. Everta). Int.J.Curr.Microbiol.App.Sci. 6(8): 646-655. doi: https://doi.org/10.20546/ijcmas.2017.608.082 